\begin{tabular}{|l|l|l||}
\hline \multicolumn{2}{|c|}{ PublisherInfo } \\
\hline \hline PublisherName & $:$ & BioMed Central \\
\hline \hline PublisherLocation & $:$ & London \\
\hline \hline PublisherImprintName & $:$ & BioMed Central \\
\hline \hline
\end{tabular}

\title{
Exercise asthma and inflammatory cytokines
}

\begin{tabular}{||l|l|l||}
\hline \multicolumn{2}{|c||}{ ArticleInfo } \\
\hline \hline ArticleID & $:$ & 1636 \\
\hline \hline ArticleDOI & $:$ & $10.1186 /$ rr-2001-68568 \\
\hline \hline ArticleCitationID & $:$ & 68568 \\
\hline \hline ArticleSequenceNumber & $:$ & 47 \\
\hline \hline ArticleCategory & $:$ & Paper Report \\
\hline \hline ArticleFirstPage & $:$ & 1 \\
\hline \hline ArticleLastPage & $:$ & 3 \\
\hline \hline & & RegistrationDate $: 2001-9-19$ \\
& $:$ & Received \\
ArticleHistory & $:$ 2000-10-27 \\
& Accepted $\quad$ 2001-9-19 \\
\hline \hline ArticleCopyright & $:$ & Biomed Central Ltd2001 \\
\hline \hline ArticleGrants & $:$ & \\
\hline \hline ArticleContext & $:$ & 129312211 \\
\hline \hline
\end{tabular}


Jeffrey Fedan, ${ }^{\text {Affl }}$

Corresponding Affiliation: Aff1

Aff1 National Institute for Occupational Safety and

Health, Morgantown, WV, USA

\section{Keywords}

Exercise asthma, hyperosmolarity, inhaled steroids, MAP kinase pathways

\section{Context}

Exercise elicits airway obstruction in asthmatic patients (exercise-induced asthma, [EA]), which may be manifest as early and late phases, the latter involving an inflammatory component. The mechanisms involved in EA have not been clarified, but released mediators (eg histamine) may play a role. During exercise the airway wall cools by a few degrees and the airway surface liquid (ASL) becomes somewhat hyperosmotic (40-60 mOsm) due to evaporative water loss. The authors have investigated whether hyperosmotic solution or cooling and re-warming of cultured bronchial epithelial cells (BEC) gives rise to the release of pro-inflammatory mediators (interleukin [IL]-8 and RANTES [regulated upon activation, normal $\mathrm{T}$ cell expressed and secreted]) and activation of mitogen-activated protein (MAP) kinase pathways (p38 and c-Jun- $\mathrm{NH}_{2}$-terminal kinase [JNK]) and whether two inhaled steroids used to treat asthma inhibit these responses.

\section{Significant findings}

A $10 \mathrm{~min}$ challenge of the BEC with $1280 \mathrm{mOsm} / \mathrm{kg}$ solution (increased by approximately 990 $\mathrm{mOsm} / \mathrm{kg}$ over culture medium by adding $\mathrm{NaCl}$ ) elicited within $24 \mathrm{hr}$ the production of IL-8 and RANTES. This response was inhibited by budesonide or beclomethasone following pretreatment $(1 \mathrm{~h})$ with the steroid. Likewise, cooling (to $0 \mathrm{RC}$ for $2 \mathrm{~h}$ ) and rewarming (to 37\&\#176\#C) stimulated IL-8 and RANTES production in a seroid-inhibitable manner. Responses to hyperosmolarity were approximately 10 -fold greater than responses to temperature jumps. Cooling of the cells, and hyperosmolar challenge, led to activation of $\mathrm{p} 38$ and JNK, but these responses were not blocked by the steroids. The release of inflammatory mediators could contribute to the late phase inflammatory response in EA. 


\section{Comments}

It is logical to investigate the involvement of $\mathrm{p} 38$ and JNK in responses to hyperosmolar challenge, since this procedure causes cell shrinkage and these pathways are known to be involved in cell volume regulation of other cells (kidney, liver). Likewise, examination of the effects of cooling is relevant to understanding the mechanisms of EA. It is significant that these authors have reported that hyperosmolarity and cooling/rewarming should provoke the release of the inflammatory mediators via a steroid-sensitive pathway. As the authors acknowledge, this pathway may not involve p38 or JNK since the kinase responses were not sensitive to the steroids. Thus, a convenient link between osmolarity, mediator production and the kinase pathways is still missing. On the negative side the study may be criticized for the extreme conditions used to provoke the release of the mediators and the activation of the kinase pathways; they have no pathophysiological relevance. Nevertheless, this study provides a fresh way of looking into possible mechanisms of EA.

\section{Methods}

Cell culture, western blots

\section{Additional information}

\section{References}

1. Hashimoto S, Gon Y, Matsumoto K, Takeshita I, Maruoka S, Horie T: Inhalant corticosteroids inhibit hyperosmolarity-induced, and cooling and rewarming-induced interleukin-8 and RANTES production by human bronchial epithelial cells. Am J Respir Crit Care Med. 2000, 162: 1075-1080.

This PDF file was created after publication. 